ENTREPRENEURSHIP AND SUSTAINABILITY ISSUES

ISSN 2345-0282 (online) http://jssidoi.org/jesi/ 2019 Volume 7 Number 1 (September)

http://doi.org/10.9770/jesi.2019.7.1(22)

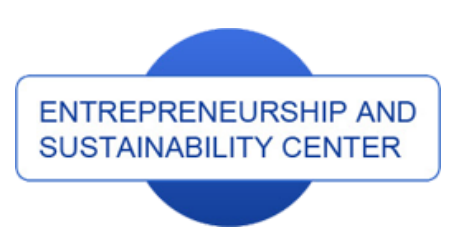

Publisher

http://jssidoi.org/esc/home

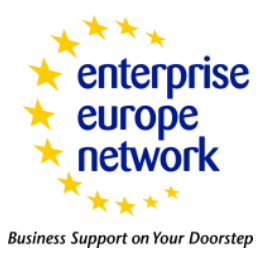

CASPA

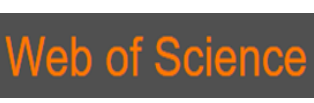

1) Clarivate

\title{
PROJECT TOOLS IN RELATION TO THE IMPLEMENTATION OF THE ABILITY OF INNOVATION COMPANIES IN SLOVAKIA*
}

\author{
Hana Krchová \\ School of Economics and Management in Public Administration in Bratislava, Furdekova 16, Bratislava, 851 04, \\ Slovak Republic \\ E-mail: hana.krchova@vsemvs.sk
}

Received 15 March 2019; accepted 10 July 2019; published 30 September 2019

\begin{abstract}
The ability of project implementation is considered an important part of corporate reality. The current situation shows that project management is used not only in technology-oriented companies but has also found its place in other areas, mainly because of the effective implementation of the necessary corporate innovations. This article intends to analyze the use of project tools in various types of companies, including public institutions in the Slovak Republic. For the verification of the use of these tools, a random selection of 154 companies implementing projects in the Slovak Republic was used. In the research, we performed a cluster analysis and multivariate regression analysis. The results show the differential use of individual instruments not only in terms of the size of companies but also in terms of realized types of projects. The most important project management procedures are related to team communication, but also to clients and external experts. The results also show that the effective use of tools, especially in the project implementation phase and completion, significantly improves the success of projects.
\end{abstract}

Keywords: project; project tools; success project; project management

Reference to this paper should be made as follows: Krchová, H. 2019. Project tools in relation to the implementation of the ability of innovation companies in Slovakia, Entrepreneurship and Sustainability Issues 7(1): 291-302. http://doi.org/10.9770/jesi.2019.7.1(22)

JEL Classifications: D83, O22, M15, H430

\section{Introduction}

Projects and innovations are ubiquitous in our professional and private life - we live in the project company (Lundin et al., 2015) and in innovative companies (Rammert et al., 2015). Project management is undoubtedly one of the main topics within most organizations. It is increasingly used in various fields of business, but also in a

\footnotetext{
* The paper is the output of an international scientific project IGA no. 2/2018 - M "Problems and Suggestions - Comparison of Commercial Environment between China - Slovakia and Facilitation of Trade and Investment”. (Funder: VSEMvs IGA VSEMvs, i.e. School of Economics and Management in Public Administration)
} 


\section{ENTREPRENEURSHIP AND SUSTAINABILITY ISSUES}

ISSN 2345-0282 (online) http://jssidoi.org/jesi/

2019 Volume 7 Number 1 (September)

http://doi.org/10.9770/jesi.2019.7.1(22)

variety of subjects from start-ups and small businesses to multinational corporations. Project management serves as a very valuable application platform primarily for the business innovation process.

One of the many questions that companies ask is: Does the organization with a higher degree of Project Management maturity achieve better project results? The answers to this are trying to bring various studies compiled by various institutions (PMI, IPMA, KPMG, EY). First, it is necessary to evaluate the real use of project management tools. As shown by a recent global survey of the use of project management is still a big part of the project does not meet its objectives (APM, 2015 PMI, 2018 Standish Group, 2018). Although the use of project tools is gradually improving (KPMG, 2017, PMI, 2018), there is still a clear gap and disproportion between use across sectors.

Projects have become a ubiquitous means of organizing work not only within the industrial enterprises (Midler, 1995) but also in the work of professional sectors, such as research, education, health, culture, sport, politics and public administration (Supeková, 2014; Petrenko, Stolyarov, 2019). The consequence of this trend is that projects spending more time and that projects from a larger value (Schoper et al., 2016). According to the surveys, which were recently implemented (PMI, 2018, Standish Group, 2015) is the application of project management in business management is increasingly used not only ICT companies. It is increasingly being used in various areas of business, regardless of size, i.e. both small and multinational. The importance of using the growing need for effective implementation of innovations. Of course, the implementation of complex innovations and changes is not only related to the actual use of project management tools, but also to the surrounding conditions that allow such changes to be made.

\section{Project management}

Project management is undoubtedly one of the main themes in most organizations. Project management serves as a very valuable application platform for the business innovation process. Currently, projects are very diverse and can have different goals, needs, and requirements. In addition, we find in the literature a lot of different definitions of projects. As part of our investigation, we are inclined to define from the PMBOK ${ }^{\circledR}$ Guide and the EY project definition. "The project is a temporary effort to create a unique product, service or result project" (PMI, 2017). EY defines a project as a "one-time process consisting of a set of synchronized and managed activities with a defined start and end date that is implemented to achieve the goal (taking into account time, cost and resource constraints) and that meets specific predefined requirements" (EY, 2017).

Perhaps the most popular word of each expert for the project is "success" (Howsawi, Fager, Bagi \& Niebecker, 2014). There are two main concepts of success when we talk about projects: project success and successful project management. There are similarities and differences between the two dimensions of project success (De Wit, 1988, Serrador, Turner, 2015). The main difference is the linking of the project success with the result of the achievement of the goals achieved, while the success of the project management concerns traditional time, cost and quality measurements (De Wit, 1988, Jugdev, Müller, 2005, Ika, 2005). However, given the many different models for the success of both project and project management, it is difficult to distinguish strongly between them, mainly because of their interrelationships.

Much of the project does not meet its objectives (APM, 2015, PMI, 2018, Standish Group, 2018) and only 40\% of project objectives are in line with the organizational strategy (PMI, 2018). This is especially true when there is increased pressure from senior management on project managers to demonstrate the benefits of the project (Lappe and Spang, 2014, Mir and Pinnington, 2014). This requires a robust Benefit Management process for active management and continuous alignment of project outputs, results, benefits and organizational strategy (Zwikael and Smyrk, 2015). 


\section{Slovak innovation environment}

Innovative projects in companies typically include the development of new products and new processes (Bresnen, Edelman, Newell, Scarbrough, \& Swan, 2003), which are associated with opportunities for emerging new ideas and strengthening the potential of companies' innovative potential. Such projects can be seen as drivers of innovation and change, and organizations can innovate through projects (Davies \& Hobday, 2005, Shenhar \& Dvir, 2007). The common transformation of all innovation projects is the creation of an adequate environment that enables people to create innovative projects (Winch, 2014).

The situation in Slovakia in terms of the ability to implement innovations can be considered complicated. On the one hand, it is because, according to the European Innovation Index, Slovakia ended in 23rd place (European Commissin, 2018). This current situation means that Slovakia is the last in the creation of knowledge, innovation, and entrepreneurship, and only a slightly better rating was given to Slovakia in the group of innovative support, mainly due to the education of the young generation. Financing innovation is very problematic from the evaluation. Slovakia is heavily dependent on EU funding for research and development. This is because private sector investment in innovation is insufficient. Development financing innovation can be seen in Figure 1 below.

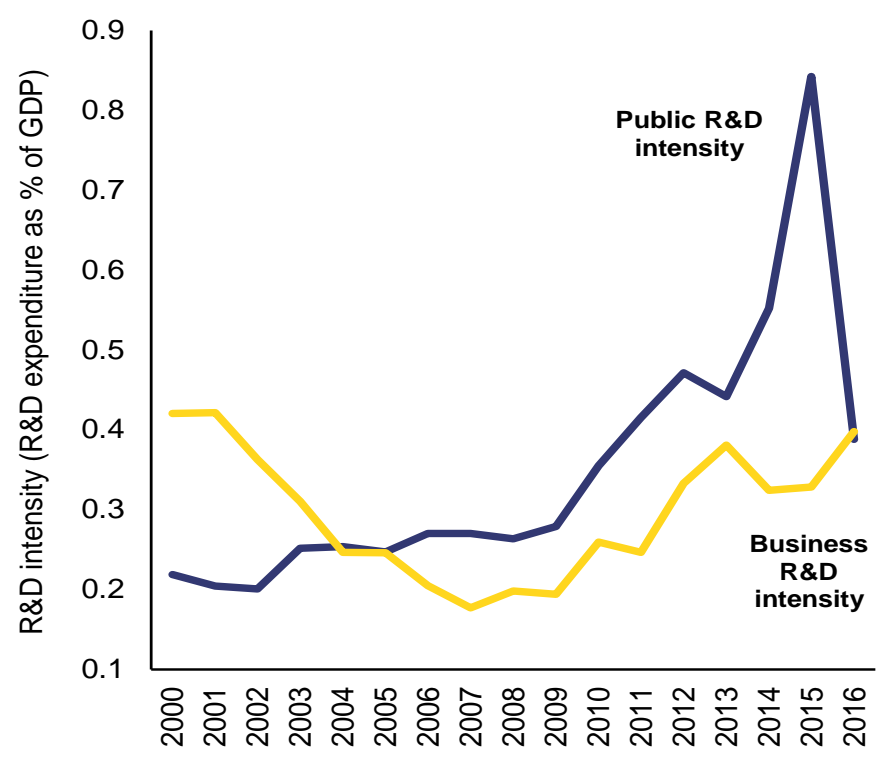

Figure 1. RDI investment by sector Source: European Commission

Figure 1 shows a sharp decline in the public R\&D financial envelope in 2016, caused by the transition between EU funding periods. This fact highlights the over-reliance of Slovak research at European structural and investment funds and raises questions about the sustainability and adequacy of national funding for research and development.

$R \& D$ spending by enterprises is very low to significantly increase innovation performance. Overall, the research and development of enterprises, one of the smallest in the EU and focuses on the production of medium to hightech, in areas dominated by multinational companies (European Commission, 2019). Corporate spending on 


\section{ENTREPRENEURSHIP AND SUSTAINABILITY ISSUES}

ISSN 2345-0282 (online) http://jssidoi.org/jesi/

2019 Volume 7 Number 1 (September)

http://doi.org/10.9770/jesi.2019.7.1(22)

research and development by small and medium-sized enterprises, which in 2016 were at $0.14 \%$, are to be found still significantly below the EU average. As a result, making very little progress in innovation and in accordance with European summary innovation results, Slovakia remains one of the innovators of undistinguished (European Commission, 2019). The main factors limiting innovation activities are cost factors (Benešová, Kubičková, Michálková, \& Krošláková, 2018). According to the survey Statistical Office of the Slovak Republic (ŠÚRS, 2019), considers the lack of financial resources within the company as an innovative barrier highest $29 \%$ of enterprises, the prohibitive costs of innovation $25.9 \%$ and the shortage of funds on loans, $10.2 \%$ of enterprises.

The above information shows that the Slovak innovation environment still has a long way to go for an ideal situation. In our opinion, however, the right use of project tools in the implementation of innovations could make Slovak firms considerably more efficient

\section{Current status of project management in Slovakia}

The main aim of our research was to evaluate the current state of project management in Slovakia and to analyze determinants influencing the quality of project management in this area. The processing of the information was necessary to focus on the primary data obtained during the research project IGP 3/2016. As part of our primary research, we approached 154 companies that implement projects in Slovakia. The research was conducted in December 2018 and the final number of respondents was 395. Finally, the survey yielded 154 applicable responses, so the response rate was 39\%. Given the specifics of the study and the method (online questionnaire Google form), the response rate was satisfactory

The research methodology was subordinated to the aim of the objectives and content of the paper. Companies surveyed were interviewed a total of 32 questions. When creating the questionnaire, we were inspired by the survey conducted by PMI and EY, which are conducted by a project management survey in the Czech Republic (EY, 2017). We used some questions equally formulated to compare these results. Our research focuses on three main areas:

1) Project Management Tools - There was investigated primarily what project management tools used by individual companies. The evaluation was also the survey, according to which standards the company implements project management or project which uses software tools.

2) Realized projects - In this area was determined by the number of completed projects, types of projects implemented. We focused on the issue of compliance with a prescribed time scale and budget of the project in its implementation and to evaluate the success of the projects themselves.

3) Project Manager and Training - This section is focused on the person of the project manager. His position within the company, in education or in remuneration.

The results are presented in the form of graphs and tables designed using computer software. We also used logiccognitive methods. Based on these analyses, it is an analysis of the current state of the project environment in Slovakia.

\section{Research Results}

This part is focused on the presentation of research results on the use of project management in Slovakia. In the research, we performed a cluster analysis and multivariate regression analysis. The dependent variable in multidimensional regression analysis was the desired level of use of project tools, an independent variable subcomponent of the tested group of project tools. 
ENTREPRENEURSHIP AND SUSTAINABILITY ISSUES

ISSN 2345-0282 (online) http://jssidoi.org/jesi/ 2019 Volume 7 Number 1 (September) http://doi.org/10.9770/jesi.2019.7.1(22)

Table1. Categorization of business by region

\begin{tabular}{|lcccccccc|} 
& BA & TN & TT & NR & ZA & BB & PO & KE \\
\hline Absolute frequency & 52 & 10 & 11 & 18 & 12 & 37 & 8 & 4 \\
\hline Relative frequency & $33,77 \%$ & $6,49 \%$ & $7,14 \%$ & $11,69 \%$ & $7,79 \%$ & $24,03 \%$ & $5,19 \%$ & $3,90 \%$ \\
\hline
\end{tabular}

Table 1 shows that most of the business involved in our survey are from Bratislava and Banská Bystrica region; lower is the number of business from Nitra, Trenčín, Žilina, and Trnava region (Figure 2). The lowest number of companies involved in our survey are from Prešov and Košice region.

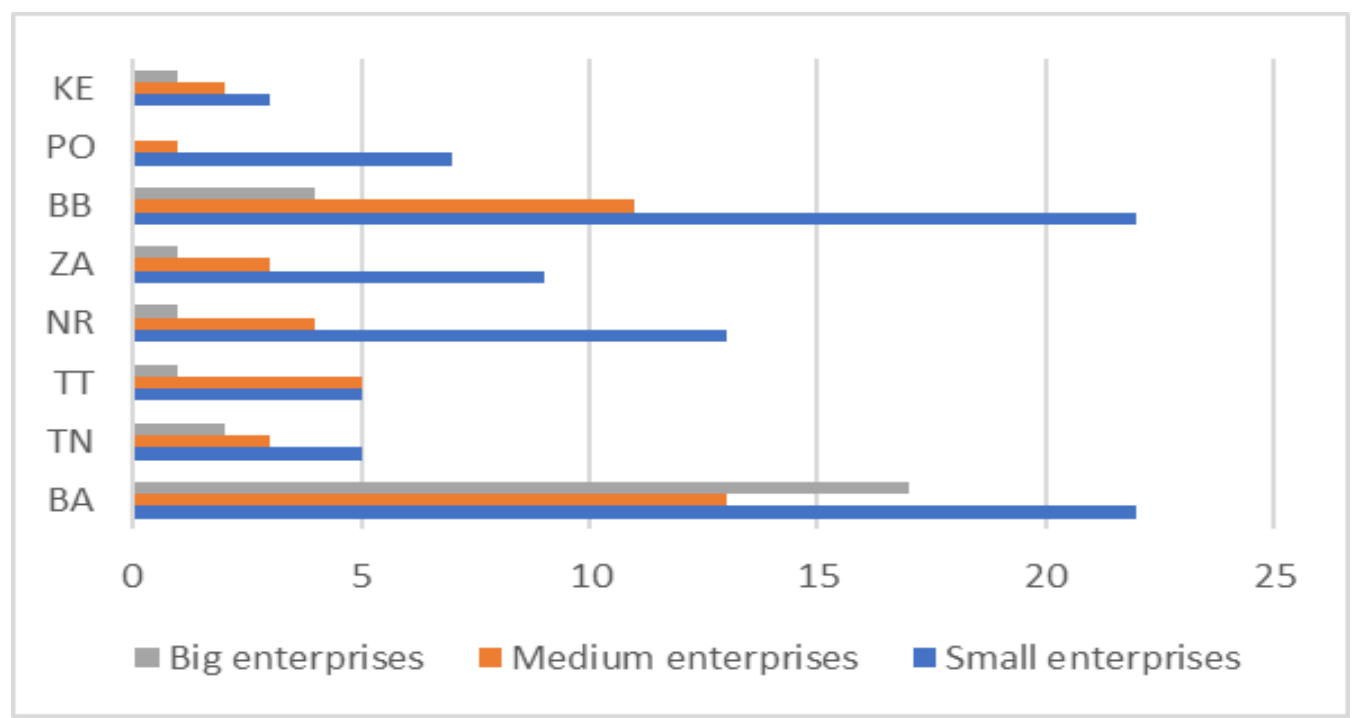

Figure 2. Categorization of business by region according to their the organizational and legal form Source: the author

The total number of types of enterprises by size it was in our survey represented $54 \%$ of small businesses, $27 \%$ of SMEs and $19 \%$ of large enterprises.

First, we focused on the amount and size of the projects implemented. In our survey, we can see that the number of implemented internal projects has increased slightly in recent years. In $31 \%$ of respondents, the number of projects is growing, $11 \%$ is falling and $48 \%$ is unchanged. Furthermore, our research and our experience show that while growing complexity of projects - their interdependence, the number of stakeholders and the complexity of requirements. Along with the growth of experience in project management are also increasing demands on the management of new projects. According to information from respondents, half of the projects exceeded the budget of 40 thousand EUR (Figure 3). 


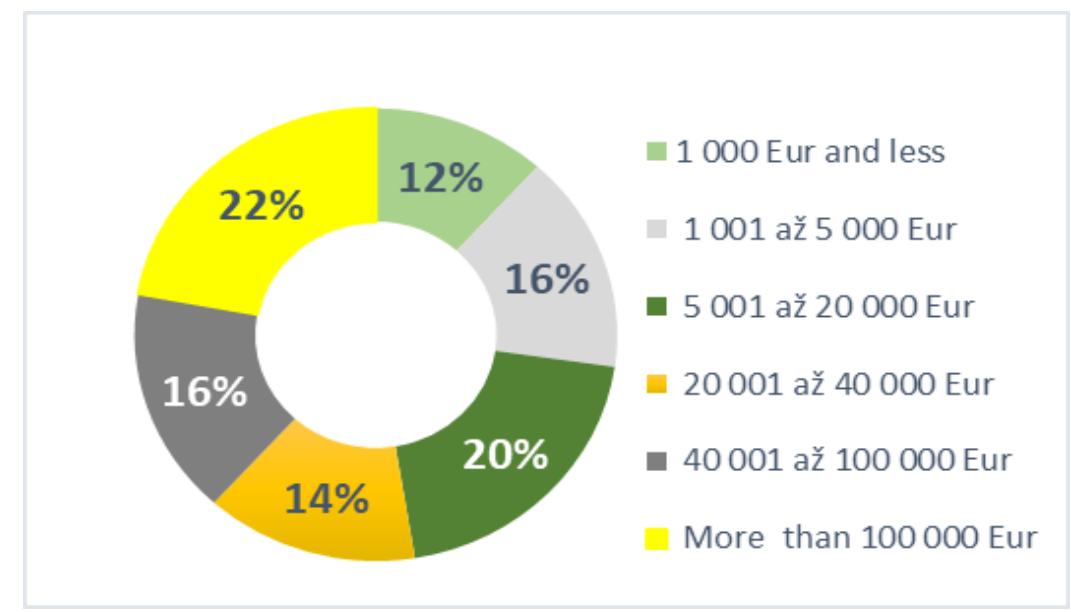

Figure 3. Project budgets in 2018 Source: the author

As part of the survey, we investigated whether and what companies in Slovakia are using project management standards. Respondents' answers showed that the most used project management standards include internal standards (66\%), PMI (18\%) and IPMA (7\%).

An important part of the survey was the success of the projects. Here, based on respondents' answers is exceeded by common budget practice for almost $15 \%$ of the projects exceeded the budget by $21 \%-50 \%$. The survey shows that $29 \%$ of the projects exceed the deadline by more than $20 \% .46 \%$ of projects will end in the planned deadline and budget. The most frequent reasons for overruns and schedule respondents said:

- Change project scope due to poor project identification (54\%)

- Consequences of external changes (51\%)

- Insufficient staffing of the project team (48\%)

- Insufficient supplier management and consequent weak control (47\%)

- Communication Problems (41\%)

- Different expectations of project outputs (32\%)

- Weak Project Management (30\%)

If we look at the most frequently realized types of projects in the last two years, up to $51 \%$ of the implemented projects were construction projects. As the second most frequent projects are modernization projects, including IT systems integration. The third most common type of projects is cost reduction projects, and the fourth type is standard new product development projects $(28 \%)$. This fact reflects the state of art commentary and merely illustrates the need to focus on innovative projects.

The evaluation of the results shows that the success of projects is always valuable to companies at least according to one criterion. The most frequently used assessment criteria for success of projects implemented by completion, filled with expectations and within budget. The survey shows that a large number of projects fail in the planning phase of the project (e.g. due to the wrong determination of the project, expected or badly set too optimistic budget). Factors allowing to increase project success are presented in Figure 4 below. 


\section{ENTREPRENEURSHIP AND SUSTAINABILITY ISSUES}

ISSN 2345-0282 (online) http://jssidoi.org/jesi/ 2019 Volume 7 Number 1 (September) http://doi.org/10.9770/jesi.2019.7.1(22)

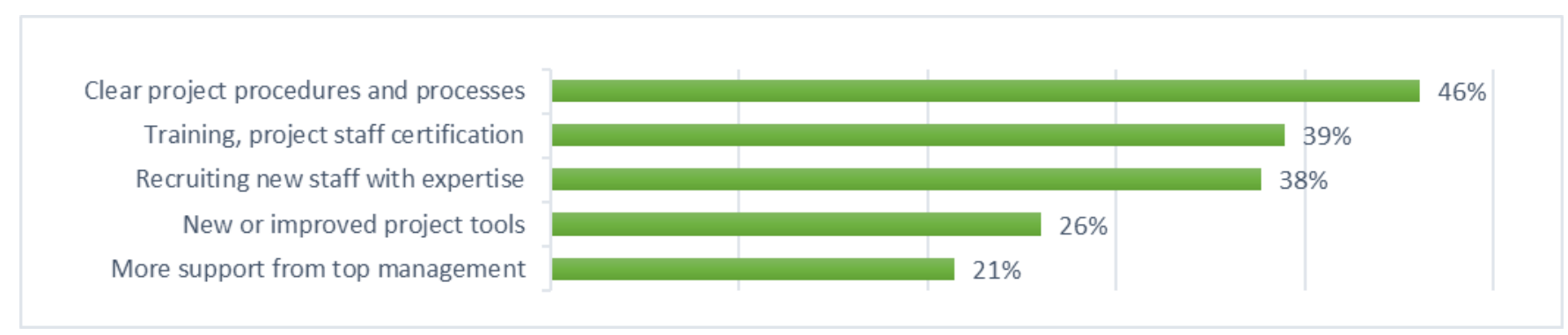

Figure 4. Factors to increase project success

Source: the author

$72 \%$ of companies reported that their project management is comparable to industry averages or better and sufficient for their purposes. 18\% of respondents expressed their self-criticism that project management in their company needs to be improved in view of future needs. Complications due to underestimation of the importance of project management and project risk management firm would avoid or minimize if involved in the process of professional project managers.

In our investigation we have divided the instruments into two large groups:

1. Tools for initiating and planning project

2. Tools for executing and closing project

In the first part of the survey the use of project tools, we focused on tools that are used in the initializing and planning of the project. The questions were focused on finding out how often and using the following tools: Business case, Project charter, Project schedule, Budget, Plan management, and Communication plan (Figure 5).

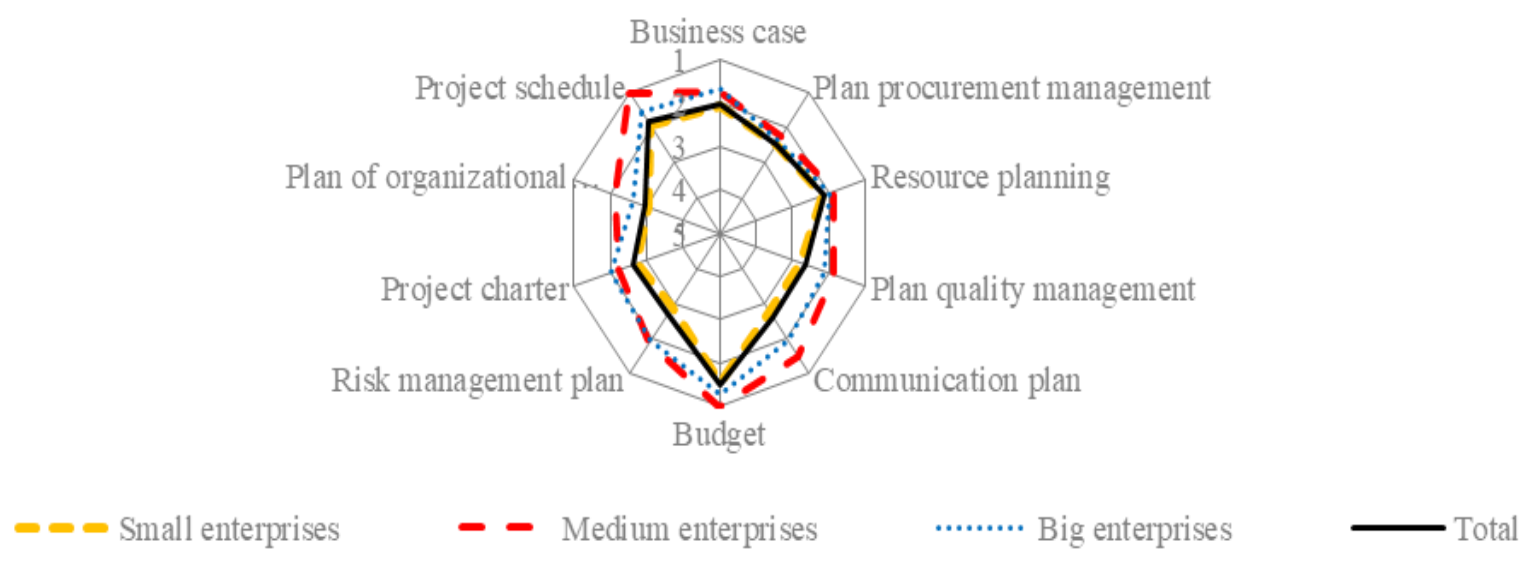

Figure 5. Tools for project initializing and planning by company size Source: the author

In the previous figure 5, you can see the results in each category in the exploration section on the use of project management tools used in project preparation and planning. The figure shows different uses of these tools in general and size of enterprises. The results show that the most used tool is clearly the project budget. The second most used tool is the project plan. Both tools are the most widely used tools, regardless of enterprise size. On the other hand, the least used tools are organizational change planning and risk plan. The figures show that the results of small enterprises are basically tracking overall results. The situation for medium and large enterprises is clearly 
better in all categories. The evaluation also shows that medium-sized enterprises are used to a greater extent than those of large enterprises.

The second part of the survey evaluated the use of tools that are used in project executing and closing. Evaluated tools in our survey were: Risk Register, Assigning Roles, Issue Log, Change Status Control, Project Status Report, Acceptance Procedures, Lessons Learned, Knowledge Databases and Evaluation of Project Team Members. Also, during the second part of the survey, we focused not only on the overall results but also on the results by company size (Figure 6).

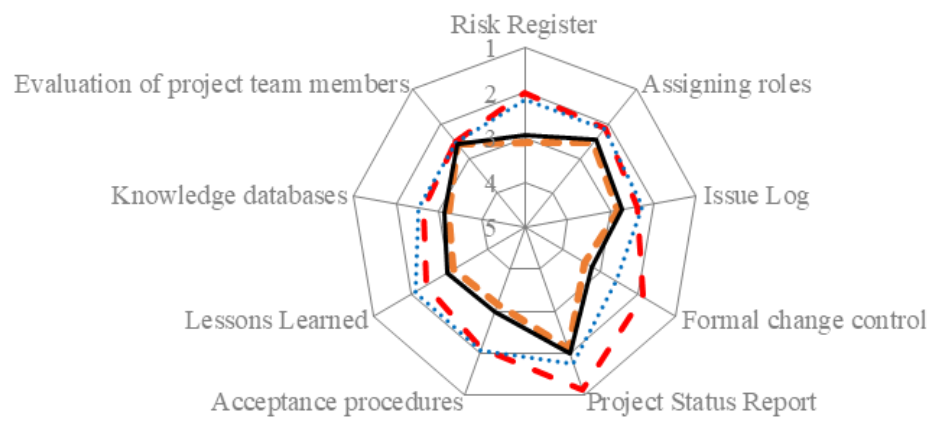

- Small enterprises $\quad$ - $\quad$ Medium enterprises $\quad \cdots \cdots . . .$. Big enterprises $\quad$ Total

Figure 6. Tools for project executing and closing by company size Source: the author

Figure 6 shows that as in the previous survey project of the instruments used in the initializing and planning as well as the results of this small company basically replicate the overall results of the sample. The most used tool in the implementation and completion of the project can be considered a Project Status Report. Other tools have a significant gap in their enjoyment. The least used tools are Formal change control. With this tool, it is interesting that medium-sized enterprises use relatively often, and on the other hand, small enterprises basically only rarely. A similar situation can be seen in the case of instruments Risk Register. Overall, Figure 7 shows significantly less use of these project tools than in the project preparation and planning section.

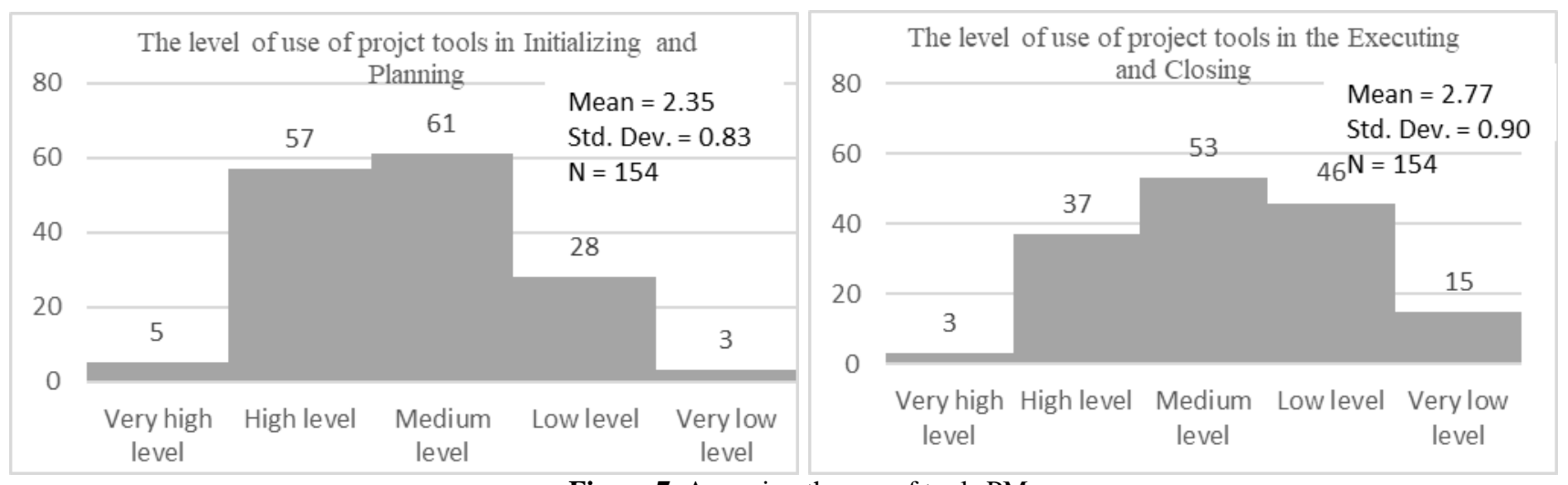

Figure 7. Assessing the use of tools PM

Source: the author 
Figure 7 shows the different level of use of project tools. On the one hand, we have initializing and planning tools where the dominance of enterprises (87\%) has reached medium and higher levels of use of these tools. In $43 \%$ of enterprises we can reach High level and Very high level. On the other hand, in the assessment of the level of project tools in executing and closing at least medium level, 26\% of companies achieved fewer and even $40 \%$ of enterprises consider even insufficient to be clearly inadequate. The results show that, while most enterprises try to use project tools in a project initiating and planning, they are not already using these tools in their executing and closing phases of the project, or what often can lead to budget, or project time being exceeded.

In our evaluation, we focused on the use of different project management tools. The following table 2 shows the most and least used project tools in Slovak enterprises.

Table 2. Use of project management tools in Slovakia

\begin{tabular}{|lr|ll|}
\hline The most used tools & \multicolumn{2}{|c|}{ The least used tools } \\
\hline Cost Budget & $85 \%$ & Formal change control & $44 \%$ \\
\hline Project schedule & $75 \%$ & Knowledge databases & $40 \%$ \\
\hline Business case & $73 \%$ & Risk Register & $36 \%$ \\
\hline Project Status Report & $72 \%$ & Acceptance procedures & $36 \%$ \\
\hline Resource Plan & $65 \%$ & Organizational change management plan & $34 \%$ \\
\hline Assign project roles & $58 \%$ & Lessons Learned & $32 \%$ \\
\hline Plan procurement management & $54 \%$ & Risk Management Plan \\
\hline Project charter & $51 \%$ & & $30 \%$ \\
\hline
\end{tabular}

It can be seen from Table 2 that the cost budget is clearly the most common tool for project management. Next is the project schedule, Business case, and Project status report. On the other hand, it is evident that the least used risk management plan or Lessons Learned.

The most important project management procedures are related to team communication, but also to clients and external experts. Most respondents reported regular status updates and standardized management and communication as important. According to the individual responses we have observed that enterprises that do not adequately evaluate the project status indicators and do not take lessons from the mistakes often exceed the deadlines and repeat them with the reasons for failure.

Overall, the level of use of project management tools in the phases of initiating and planning of the project is at a high level at $40 \%$ of enterprises, and only $20 \%$ of the enterprises are not using enough. The situation is different in the executing and closing phases of the project. Only $26 \%$ of enterprises use the tools in this phase at a high level. $40 \%$ of tool enterprises do not use enough and do not use some at all.

\section{Conclusion}

This survey deals with project management with the aim to find out how to promote the implementation of innovations and changes in Slovak enterprises. The amount of information collected was broad. As a result, we were able to identify such aspects of project management in Slovak enterprises that are related to their innovation activity. 


\section{ENTREPRENEURSHIP AND SUSTAINABILITY ISSUES}

ISSN 2345-0282 (online) http://jssidoi.org/jesi/ 2019 Volume 7 Number 1 (September) http://doi.org/10.9770/jesi.2019.7.1(22)

On closer examination, we conclude that the results of our survey show that a very neglected area in terms of project tools, the issue regarding the risks. And not only their identification but also work with the risks in terms of their systematic monitoring during the implementation and documentation for future projects. This is connected with the problematic use of tools for formal change management or the use of database knowledge. This situation leads to the fact that just "uncontrolled" risks reduce the success of projects implemented in Slovakia. That is why we can introduce work with risks on the project as one of the main weaknesses of project management in Slovakia. It is evident that when implementing innovations in enterprises, better work with risks would make their implementation more effective.

The reason for making better use of project tools within the initiating and planning phase compared to executing and closing can also by the fact that Slovak enterprises are trying to raise funds for their activities from public sources. In an effort to obtain funding for their innovation activities of enterprises faced with project documents as they are defined in the applications. Most enterprises considered these documents as simply a formal necessity in the context of the realization, when is often these documents for the management of the project does not use. And this is the reason such a large disparity between the use of different types of project tools. The real use of project tools would enable enterprises to better manage their projects and thus avoid budget overruns and project deadlines. As we mentioned above, they manage project management middle and large enterprises. Projects with a budget of 40 to 100 thousand $€$ thus achieve higher success rates $(65 \%)$ than smaller projects (42\%).

In conclusion, despite the relatively high proportion of failed projects, project management evaluation is still positive. Almost sixty percent of respondents consider it sufficient. On the other hand, over forty percent of the company wants to improve it in view of the company's future needs.

\section{Acknowledgements}

The paper is the output of an international scientific project IGA no. 2/2018 - M „Problems and Suggestions - Comparison of Commercial Environment between China - Slovakia and Facilitation of Trade and Investment". (Funder: VSEMvs IGA VSEMvs, i.e. School of Economics and Management in Public Administration)

\section{References}

APM. 2015. Conditions for project success APM research report. https://www.apm.org.uk/media/1621/conditions-for-projectsuccess_web_final_0.pdf

\footnotetext{
Benešová, D., Kubičková, V., Michálková, A., Krošláková, M. 2018. Innovation activities of gazelles in business services as a factor of sustainable growth in the Slovak Republic. Entrepreneurship and Sustainability Issues, 5(3), 452 - 466.

https://doi.org/10.9770/jesi.2018.5.3(3)
}

Bresnen, M., Edelman, L., Newell, S., Scarbrough, H., \& Swan, J. 2003. Social practices and the management of knowledge in project environments. International Journal of Project Management, 21(3), 157-166. https://doi.org/10.1016/S0263-7863(02)00090-X

Davies, A., \& Hobday, M. (2005). The business of projects: Managing innovation in complex products and systems. Cambridge, UK: Cambridge University Press.

De Wit, A. 1988. Measurement of project success. International Journal of Project Management, 6(3), 164-170.

https://doi.org/10.1016/0263-7863 (88)90043-9 


\section{ENTREPRENEURSHIP AND SUSTAINABILITY ISSUES}

ISSN 2345-0282 (online) http://jssidoi.org/jesi/ 2019 Volume 7 Number 1 (September) http://doi.org/10.9770/jesi.2019.7.1(22)

Doherty, N.F., Ashurst, C., Peppard, J., 2012. Factors affecting the successful realisation of benefits from systems development projects: findings from three case studies. Journal of Information Technology, 27(1), 1-16. https://doi.org/10.1057\%2Fjit.2011.8

European Commission, 2018. European Innovation Scoreboard 2018. http://ec.europa.eu/growth/industry/innovation/facts-

figures/scoreboards_en

European Commission, 2019. 2019 European Semester: Country Resports. https://ec.europa.eu/info/publications/2019-european-semestercountry-reports_en

EY. (2017). Průzkum projektového ř́zení $\quad$ v $\quad$ ČR $2017 \quad$ Výsledky 10 r ročníku EY průzkumu [Project Management Survey in the Czech Republic 2017 Results of the 10th EY Survey] https://www.ey.com/Publication/vwLUAssets/Projektov\%C3\%A9_\%C5\%99\%C3\%ADzen\%C3\%AD_2018/\$FILE/EY\%20Pr\%C5\%AFzk um\%20projektov\%C3\%A9ho\%20\%C5\%99\%C3\%ADzen\%C3\%AD\%20v\%20\%C4\%8CR\%202017_v\%C3\%BDsledky\%2010.\%20ro\%C4 $\% 8 \mathrm{Dn} \% \mathrm{C} 3 \%$ ADku.pdf

Howsawi, E, Eager, D. Bagia, R. Niebecker, K. 2014. The four-level project success framework: application and assessment. Organisational Project Management, 1(1), 1-15. http: //dx.doi.org/10.5130/.v1i0.3865

Ika, L.A. 2009. Project success as a topic in project management journals. Project Management Journal, 40(4), 6-19. https://doi.org/10.1002/pmj.20137

Jugdev, K. Müller, R. 2005. A retrospective look at our evolving understanding of project success. Project Management Journal, 36(4), 1931. https://doi.org/10.1177/875697280503600403

KPMG. 2017. Project Management Survey 2017. Driving business performance. https://assets.kpmg/content/dam/kpmg/nz/pdf/July/projectmanagementsurvey-kpmg-nz.pdf

Lappe, M., Spang, K. 2014. Investments in project management are profitable: a case study-based analysis of the relationship between the costs and benefits of project management. International Journal of Project Management, 32(4), 603-612 https://doi.org/10.1016/j.ijproman.2013.10.005

Lundin, R.A., Arvidsson, N., Brady, T., Ekstedt, E., Midler, Ch., Sydow, J. 2015. Managing and working in project society. Institutional challenges of temporary organizations. Cambridge University Press, Cambridge, England, p. 356.

Midler, C., 1995. Projectification of the firm: the Renault case. Scandinavian Journal of Management. 11, 363-375. https://doi.org/10.1016/0956-5221(95)00035-T

Mir, F.A., Pinnington, A.H., 2014. Exploring the value of project management: linking project management performance and project success. International Journal of Project Management, 32(2), 202-217. https://doi.org/10.1016/j.ijproman.2013.05.012

Petrenko, E., Stolyarov, N. 2019. Features of the management of international projects, taking into account intercultural differences of the partners. Entrepreneurship and Sustainability Issues, 6(4), 2037-2051. http://doi.org/10.9770/jesi.2019.6.4(34)

PMI. (2017). A Guide to the Project Management Body of Knowledge. (PMBOK® Guide) -Newtown Square, Pennsylvania: Project Management Institute.

PMI, 2018. Pulse of the Profession 2018: Success in Disruptive Times. Project Management Institute https://www.pmi.org/$\underline{\text { /media/pmi/documents/public/pdf/learning/thought-leadership/pulse/pulse-of-the-profession-2018.pdf }}$

Rammert, W., Windeler, A., Knoblauch, H., Hutter, M. (Eds.). 2015. Innovationsgesellschaft heute. Springer.

Serrador, P., Turner, J.R. 2015. The relationship between project success and project efficiency. Procedia-Social and Behavioral Sciences, 119, 75-84. https://doi.org/10.1002/pmj.21468

Shenhar, A. J., \& Dvir, D. (2007). Reinventing project management: The diamond approach to successful growth and innovation. Boston, MA: Harvard Business School Publishing., p 232. 


\section{ENTREPRENEURSHIP AND SUSTAINABILITY ISSUES}

ISSN 2345-0282 (online) http://jssidoi.org/jesi/ 2019 Volume 7 Number 1 (September)

http://doi.org/10.9770/jesi.2019.7.1(22)

Shenhar, A.J. Dvir, D. 2007. Project management research - the challenge and opportunity. Project management journal, 38(2), 93-99. https://doi.org/10.1177/875697280703800210

Schoper, Y., Gemünden, H.G., Nguyen, N.N., 2016. Fifteen future trends for project management in 2025. In: Knöpfel, Hans, MartinezAlmela, Jesus (Eds.), Future Trends in Project, Programme and Portfolio Management 2016. Proceedings of the International IPMA Expert Seminar in Zurich in February 18-19, 2016, pp. 23-43. https://re.public.polimi.it/retrieve/handle/11311/1019866/197284/ExpSemProc16rzd.pdf

Standish Group, 2018. CHAOS Report: Decision Latency Theory (2018). https://www.standishgroup.com/store/services/10-chaos-reportdecision-latency-theory-2018-package.html

Supeková, S. 2014.International Business IV. Vol. 2, Project management. 1st ed. Nitra: ForPress Nitrianske tlačiarne. ISBN 978-8089731-20-6

Štatistický úrad Slovenskej Republiky. 2018. Innovation activity of enterprises in the Slovak Republic 2014 - 2016.

https://slovak.statistics.sk/wps/wcm/connect/252f80f5-0daf-49c5-b315-

15a296e69dad/Inovacna_aktivita_podnikov_v_Slovenskej_republike_2014_2016.pdf?MOD=AJPERES\&CACHEID=ROOTWORKSPAC E-252f80f5-0daf-49c5-b315-15a296e69dad-munA5VE

Winch, G. M. 2014. Three domains of project organising. International Journal of Project Management, 32(5), 721 -731.

https://doi.org/10.1016/j.ijproman.2013.10.012

Zwikael, O., Smyrk, J., 2015. Project governance: balancing control and trust in dealing with risk. International Journal of Project Management 33(4), 852-862. https://doi.org/10.1016/j.ijproman.2014.10.012

Hana KRCHOVÁ, Ph.D. is an Assistant Professor of the Department of Management, School of Economics and Management in Public Administration in Bratislava, Slovak Republic. Her research interests are: Projects, Project Management, Innovation Management, and Strategic Management.

ORCID ID: orcid.org/0000-0003-3550-5300

Register for an ORCID ID:

https://orcid.org/register

Copyright (C) 2019 by author(s) and VsI Entrepreneurship and Sustainability Center

This work is licensed under the Creative Commons Attribution International License (CC BY).

http://creativecommons.org/licenses/by/4.0/

(c) (i) Open Access 